\title{
COVID-19 Salgını, Küresel Elit ve Yeni Düzen
}

\section{COVID-19 Salgını, Küresel Elit ve Yeni Düzen $\ddot{O}_{z}$}

Dünyayı gerçek anlamda devletler ve Birlemiş Milletler gibi uluslararası kurumların mı yoksa küresel elitin elinde yoğunlaşan sermayenin mi yönettiği önemli bir tartışma konusudur. Son iki yıldır yaşanan gelişmelerin ulus-devletlerin egemenliğine dayalı sistemin yerine tam anlamıyla küresel elitin kontrolünde bir tek dünya hükümetinin kurulmasına hizmet edip etmediği de bir başka tartışma konusudur. CFR, Bilderberg, Chatham House gibi kurumlar biçiminde yapılanan karar alma mekanizmalarına sahip olan bu elitin bazı tanınmış iş insanları vasıtasıyla genetiği değiştirilmiş ürünler ve aşılarla ilgili yeni bir çalışma alanı başlattığı bilinmektedir. Bu bağlamda, bugün yaşadığımız COVID-19 salgını, son 30 yılda MERS, SARS, H1N1 gibi pandemik denemelerin son ürünüdür. Amacın dünya nüfusunu zorunlu dijital kimliğe geçirmek, ülke ekonomilerini karantinalarla çökertmek ve tek dünya devletine geçişi sağlamak olduğu düşünülmektedir. Bu çalışmada, bu planın detayları, içinde bulunduğumuz büyük başlangıcın nereye doğru evirileceği üzerine düşünce üretilmiştir.

Anahtar Sözcükler: koronavirüs, aşı, büyük başlangıç, dijital kimlik, küresel elit

\author{
COVID-19 Pandemic, Global Elite and New Order \\ Abstract
}

Whether the world is indeed governed by international institutions such as states and the United Nations or by the capital concentrated in the hands of the global elite is an important debate. It is another matter of debate whether the developments in the last two years serve to establish a single world government under the complete control of the global elite instead of the system based on the sovereignty of nation-states. It is known that this elite, which has decision-making mechanisms structured in the form of institutions such as CFR, Bilderberg, Chatham House, has started a new field of work on genetically modified products and vaccines through some well-known business people. In this context, the COVID-19 epidemic we live in today is the end product of pandemic trials such as MERS, SARS, H1N1 in the last 30 years. It is argued that the aim is to pass the world population to compulsory digital identity, to collapse the national economies with quarantines and to ensure the transition to a single world government. This study focuses on the details of this plan and where the great beginning we are in will evolve.

Keywords: coronavirus, vaccine, big beginning, digital identity, global elite

\section{Giriş}

Küresel koronavirüs salgını süresince insanlar evlerine kapanmış, hastalığa yakalanmamaya çalışırken gündelik yaşama dair birçok şey değişime uğramıştır. Bazı alışkanlıklar unutulmaya yüz tutturmuştur. Yaza kadar bir çare bulunur diye umut edilirken henüz salgına karşı bir çözüm bulunamamıştır. Aşıların deneme sürecinin de aslında ne ölçüde tamamladığı ciddi merak konudur. İnsanların bekleyişi devam ederken sadece kış mevsimi olduğu için değil, gerçekten karanlık zamanlarda yaşadığımıza dair bir gidişatın güçlü emareleri belirmektedir. İnsanlar geleceklerini görememekte, ne olup-bittiğini anlayamamakta, neler olacağının öngörüsünde bulunamamaktadır. Endişeler daha çok bireylerin kendileri, aileleri ve sevdikleriyle ilgilidir. Ama şu anda sadece insan hayatı değil, devletlerin varlığı ve temel özgürlükler de tehlikededir.

İnsanlık gerçekten karanlık zamanlarda yaşamaktadır. Bozulmakta olan psikolojiler, kötüye giden ekonomik ve sosyal hayat bir yana, hiç istenmeyecek yeni bir dünya insanllğ 1 beklemektedir. Büyük başlangıcın 2030 yılına kadar olan bir iş planı söz konusudur. Bu makalede, karanlık gelecek, bu geleceğin büyük başlangıcı ve insanlığ bekleyen en kötü senaryo değerlendirilecektir. Ama önce koronavirüs ve aşılar ile ilgili gelişmelere kısaca değinilecektir.

\footnotetext{
${ }^{1}$ Prof. Dr. Sait Y1lmaz, Istanbul Esenyurt University, Faculty of Business and Management Sciences, Department of Political Science and International Relations, Istanbul-TURKEY, syilmaz39@ hotmail.com, ORCID: 0000-0001-74431856
} 


\section{Koronavirüs ve PCR Testleri ile İlgili Az Bilinenler}

Koronavirüsü (COVID-19 veya SARS-CoV-2), tıpkı grip gibi viral bir hastalıktır. Zaten geliştirilen aşılar da grip aşısı için yapılan çalışmaları esas almıştır. Ancak, aşı tedavi etmez sadece virüsü önlemeye yarar. Grip aşılarının etkinliği yüzde 20-50 dolayındaydı. İlaç -yani tedavi- olarak, bakterilerin çaresi bulundu: Antibiyotikler. Ancak virüslerin çaresi bulunamadı. Çin ve Küba'nın sıtma ilacı olan hidroksiklorokin kullanarak geliştirmeye çalıştığı bir ilaç vardır. Bunun dışında yapılacak şey, bağışıklık sistemini güçlendirecek vitaminler almaktır.

Virüs, gerçek ama elde bir örneği yoktur. Öte yandan, koronavirüsün kanıtı da yoktur. Yani virüsün orijini nedir, belli değildir. Viral parçacıklar mı, hücre döküntüleri mi, saf mı bozulmuş mu, hangi tür parçacık, bunlarla ilgili net bilgi yoktur. Saf olmayan bir virüs izole edilemez ve RNA özellikleri belirlenemez. Yapılmakta olan klinik deneyler, virüs RNA'sının hastalığın nedeni olduğunu gösteren kanıtlar da sunmamıştır (CDC, 2020).

Özetle, koronavirüs, bir gerçeğe değil, inanca dayanmaktadır. Staller'a (2020) göre COVID19 ve türevleri ile ilgili ulaşılan sonuçlar şunlardır:

(1) Virüs yeni değildir. Çin'de ortaya çıkan koronavirüs güçlü bir şekilde Sars-1 ile alakalidir.

(2) Önceki örneklerine bakılarak (Sars, Sars-CoV-2), halkın bir kısmının virüse karşı bağışıklık kazandığı, yani sürü bağışıklığı beklentisi de doğru değildir.

(3) Bazı insanların herhangi bir belirti göstermeden bu hastalığı atlattığ 1 da yanlış bir inançtır.

COVID-19 tanısında kullanılan PCR testlerinin istatiksel olarak büyük oranda doğru olmayan pozitif sonuçlar verdiği görülmektedir. Pozitif sonuçların daha çok sıradan solonum hastalıkları ile alakalı olduğu iddia edilmektedir. PCR teknolojisi, koronavirüs bulaşma testleri için değil DNA sıklıklarını yinelemek amacıyla tasarlanmıştır. Kısaca, PCR testlerinin doğruluğu çok tartışmalıdır ve bu testler genellikle doğru sonuçlar vermemektedir. PCR testi ile Pozitif Tahmin Değeri ölçülmektedir. Bu değer, iki şeye bağlıdır: Genel nüfus içinde virüsün yayılma oranı ve testin özelliği. Testin özelliği için bir değişmez veya altın standart yoktur. Yani her şey görecelidir ve her şeyin bilimsel olarak değeri çok tartışmalıdır (DeGraw, Engelbrecht ve Demeter, 2021).

PCR testleri hastalığın niceliği değil niteliği ile ilgili değerler üzerine kuruludur. Diğer bir ifadeyle, vücudumuzda ne kadar virüs olduğunu göstermemektedir. Hiçbir zaman vücudumuzda ne kadar virüs var, kanımızda ne kadarı dolaşıyor bilmiyoruz. Bütün bunların sonucu yanlış teşhislerin ölümcül tedavilere yol açabileceği gerçeğidir. Bu kapsamda ulaşılan diğer sonuçlar şu şekildedir:

(1) Virüs ile mücadelede aşıdan başka bir yöntem olmadığı dayatılmaktadır. Etkili tedavi yöntemleri ucuz yani diğer bir deyişle kârlı olmadığı için Big Pharma tarafından engellenmeye çalışılmaktadır.

(2) Virüs, daha büyük bir gündemin, uluslararası ekonomi, sağlık ve takip sistemi için bir bask1 aracı olarak kullanılmak istenmektedir.

(3) Virüs nedeniyle uygulanan karantinalarla dünya bir ekonomik felakete sürüklenmekte, ülke ekonomileri borç, işsizlik batağında çökerken, insanlar depresyona ve intihara sevk edilmektedir.

(4) Karantinalarla toplumsal hayat; okullar, din hizmetleri, sporlar, eğlence faaliyetleri, sosyal aktiviteler, alış-veriş, yemek ve çalışma yerleri dâhil tüm sosyal hayat ve alışkanlıklar darbe yemiş, dönüşüm başlamıştır. 


\section{Aşılarda Durum}

Biyoteknoloji, önce hayvanların klonlanması ile dikkat toplamıştı. Halen, DNA teknolojisi ve gen kurgusu yolu ile benzer genler bir araya getirilerek, genetik olarak değişmiş hayvanlar veya mikro-organizmalar geliştirilmektedir. Klonlama, özellikle mükemmel biyolojik ve ekonomik özellikleri olan türlerin devamını ve üremesini sağlamaktadır. Sonra genetiği değiştirilmiş ürünlerin tarımda kullanılması fikri ortaya çıkmıştır. DNA teknolojisi ile çeşitli kaynaklardan alınan genetik malzemeler tek bir hücreye enjekte edilerek protein üretilmektedir. Üretilen genetik yapısı değiştirilmiş ve sahiplenilmiş bu ürünler örneğin, Bill Gates'in Monsanto şirketinde vardır. Pek çok genetiği değiştirilmiş tohum depolanarak, gelecekte tekel oluşturmaya çalışmaktadir.

Aş1lara gelecek olursak, normal olarak günümüzde üç şekilde aşı üretilebilmektedir:

(1) Klasik aşılar, ölmüş virüsleri izole ederek, buna göre vücudun antikor geliştirmesi ve bağışıklık kazanması esasına dayanmaktadır. Geçmişteki grip aşıları buna örnektir. Ölmüş virüs parçaları aşı ile enjekte ederek, vücudun mikrobu tanıması ve mücadele etmeyi öğrenmesi sağlanmaktadır.

Çin'den alınan Sinovac aşısı ölü virüs yani aktif olmayan aşı kategorisindedir. Bu aşının nasıl geliştirildiği belli değildir. Gerekli fazlardan geçtiği de söylenememektedir. Aktif olmadığı için koruyuculuğu yüzde 50-70 dolayındadır. Yani düşük koruyuculuk oranına sahiptir ama avantajlı yanı, ikinci gruba göre riski de oldukça düşük olmasıdır. Öte yandan, yeni mutasyonlu virüse korumas1 yoktur.

(2) COVID-19 aşılarının büyük bir bölümü genetik özelliği değiştirilmiş ürünlerdir. Müşteri oranı düşmesin diye kamuoyuna resmen açıklanmasa da bu genetik ürünler öncelikle bağışıklık sistemimizi olumsuz etkileyebilmektedir. İnsan hücrelerine gönderilen farklı genetik bilgiler DNA veya RNA olarak adlandırılır. Yeniden yapılandırılmış bu RNA insan hücresine karıștığında genetik sürecimizi de değiştirmektedir. Daha da açıkçası olduğunuz aşı, vücudunuzun doğal gen dizilimine zarar verebilir ve bu sadece sizi değil, gelecek nesillerinizi de etkiler, kalıtımsal olur (Rose, 2020).

İlk onaylananlar Pfizer/BioNTech ile Moderna'nın aşılarıdır. İkisi de DNA'lara, nasıl protein üreteceğini öğreten mRNA (messenger RNA) aşısıdır. mRNA aşısı özellikle kansere karşı geliştirilmiştir ve başarısız olmuştur. Moderna'nın açıkladığı gibi, mRNA aşısı sadece iki günde Covid-19'a uyarlanmıştır. Şimdi Pfizer/BioNTech ve Moderna'nın kasaları dolarken -basitçe söylemek gerekirse- bu şirketler tarafindan geliştirilen ve mRNA teknolojisi kullanılan aşılar, insanların genlerini değiştirecek özelliklere sahiptir. Bu tür aşılar daha önce insanlar üzerinde hiç denenmemiştir. Son günlerde Avrupa'daki uygulamalarından ölüm haberleri gelmektedir.

(3) Diğer bir türdeki aşı virüse yakalanmış ve atlatmış kişilerden antikor alarak, aşı üretme prensibine dayanmaktadır ama bu, koronavirüs şartlarında pek uygulanabilir değildir.

Aşılar için çok acele edilmiştir. Hâlbuki olası genetik zararları için gerekli deney ve süreçlerin uygulanması uzun bir zaman dilimi gerektirmekteydi. Şu anda yapılan iş, RNA parçacıklarına vücudun verdiği doğal ve tesadüfî olumlu/olumsuz tepkiye dayalı PCR testleri yapmaktır. COVID-19 aşıları geliştirmek için çalışanların doğru gen okuma yetenekleri yoktur. Üretilen genetiği değiştirilmiş ürünlerin testleri, ürünlerin içinden biri tesadüfen çekilerek yapılmamaktadır. Aşı üreticileri de bunlardan muaftır. Tekrar edecek olursak genetiği değiştirilmiş aşılar, 
insan DNA'sını değiştirecek kuvvetli bir potansiyele sahiptir ve mutasyona uğrayarak gelecek nesilleri de tehlikeye atabilecektir. Gelecekte bebekler sağlıklı doğmayabilecektir.

Aşının çalışma sistemi şu şekildedir: Hücreye enjekte edildiğinde genlerinizi ele geçirir; daimi olarak yeniden programlar ve böylece antikor üreterek COVID'i öldürür (Freeman, 2021). Bu yeni proteinler sizin DNA'nız tarafından kontrol edilememektedir yani vücudunuzda tamamen yabancı olarak kalmaktadır. Aşılar deney yapılırken izole edilmiş bir virüs üzerinden çalışılmamıştır. Deneylerde kullanılanlar, kuramsal olarak bilgisayarda üretilen dijital virüslerdir (Freeman, 2020). Dolayısıyla bunların gerçek hayatta ne kadar geçerli olduğu tartışılır bir durumdur. Öte yandan deneysel COVID aşıları kişiden virüsün diğerlerine yayılmasını engellememektedir. Deneysel COVID aşıları sağlığa diğer bütün aşılardan daha zararlıdır (Lendman, 2021).

\section{Küresel Sermaye ve Nüfus Azaltma Projesi}

Yeni Dünya Düzeni'nin ilk taslağı, Londra'daki Tavistock İnsan İlişkileri Enstitüsü baş kuramcısı olan Edward Bernays tarafindan yapılmıştır (Coleman, 2006). Yeni Dünya Düzeni planı içinde küresel nüfusu azaltacak bir mühendislik çalışması (virüsler/aşılar/genetik olarak oynanmış yiyecekler), dünya nüfusunun bir milyardan aşağıya çekilmesi ve dünya kaynaklarının küresel oligarkların kullanımına bırakılması vardır. 20. yüzyılın başından beri dünyanın her yerinden virüs ve bakteri toplanarak, askeri amaçlarla üzerinde çalışılmaktadır.

Küresel sermaye kastı, bu iş için kendisine filantropi (hayırseverlik) örtüsü edinmiştir. 20. yüzyılın başlangıcında Rockefeller, Carnegie ve Ford vakıfları filantropi yoluyla bu çalışmaların finansında öncüydü. MacArthur Vakfi ile Bill ve Melinda Gates Vakfi, bu büyük vakıflar arasına katılmıştır (Hunt, 2008). Hayırseverlik amacıyla kurulmuş vakıflar, vergiden muaftır ve böylece zenginler vergi vermek yerine bir kısım parasını -Benim param! diyerek, istediği her (eğitim, din, bilim, kültür vb.) alanda kendine göre projeler için kullanmaktadır. Bu yöntem, süper zengin biri için vakıf aracılığı ile yeni emlak ve gelir elde etme yolu olarak da kullanılmaktadır (Barkan, 2013). Örneğin Bill Gates, gelirlerinin çoğunu Microsoft'tan değil bu tür işlerden elde etmektedir (Hürriyet, 2013).

Konunun genel çerçevesinin anlaşılması için yapılan çalışmaları tarihsel olarak üç dönem halinde ele alabiliriz.

(1) Soybilim çalışmaları: İkinci Dünya Savaşı sonuna kadar olan ilk döneme "soybilim” (eugenics) çalışmaları damgasını vurmuştur. 1920'lerden itibaren "negatif soybilim" çalışmaları ile arka planda istenmeyen ırk ya da nüfusun yok edilmesi hedeflenmiştir. Bunun ilk uygulaması Hitler tarafından Yahudiler üzerinde yapılırken, 1939'daki Negro Projesi'nde ise hedef siyahlard1 (Fleury, 2015). Savaştan sonra Hitler'in soybilim alanındaki bilim insanları ABD'ye getirilerek, Rockefeller Vakfı içinde çalışmalarına devam etmiştir (Engdahl, 2007).

(2) Yeşil Devrim ve GMO'lu Ürünler: 1946 yılında Nelson Rockefeller ve eski ABD Tarım Bakanı ve Hi-Bred Seed şirketinin kurucusu Henry Wallace'in Meksika'ya yaptığı bir geziden sonra Yeşil Devrim (Green Revolution) projesine karar verilmiştir. Projenin görünüşteki hedefi dünyada açlığa son vermekti. Yeşil Devrim' in amac1, ileri mekanize tarım üretimine sahip sanayileşmiş ülkelerin yavaş da olsa dünyadaki "fazla nüfus"u eriteceği idi. Yeşil Devrim işinde Rockefeller Vakfı ile Ford Vakfı el ele idi ama ABD dış politikasını desteklemek için Kalkınma Ajansı (USAID) ve CIA ile işbirliği yapılmıştır. On yıllarca başta Afrika olmak üzere dünyanın her köşesinde yapılan projeler çoğunlukla başarısız olmuştur.

1970'lere kadar yapılan Yeşil Devrim çalışmalarının sonrasında "genetik" bilimi dâhilinde genetiği değiştirilmiş organizmalar (Genetically Modified Organisms, GMO) ile tekrar nüfus 
kontrolüne geçilmiştir. Moleküler biyoloji ve genler ile ilgili çalışmalar Rockefeller Vakfi'nın yarattığ 1 bir alandır. Nüfus azaltması ve GMO’lar büyük bir stratejinin parçasıdır ve dünya nüfusunda önemli bir azaltmayı hedeflemektedir. Rockefeller Vakfı'nın büyük stratejisi içinde, bitkiler ve hayvanların genetiği ile ilgili araştırmalar iç içe devam etmiştir. Yiyecek tedariki artık aile çiftlikleri yerine çokuluslu şirketlerin işi olmalıyd1. 1970'lerde Henry Kissinger, "Petrolü kontrol ederek ülkeyi kontrol edersiniz, yiyeceği kontrol ederek nüfusu (insan sayısını) kontrol edersiniz" demişti ve onunla birlikte küresel nüfusun azaltılması ve gıda kontrolü ABD stratejisi olmuştur (Myers, 2001).

(3) Biyolojik Savaş ve Aşılar: İnsanın hayatı üzerine biyolojik savaşın babaları daha önce doğmuştur. İngilizler çiçek hastalığı bulaştırılmış battaniyeleri kullanıyordu. Amerika'ya göç eden İngilizler bu battaniyeleri Kızılderili nüfusunu yok etmek için kullanmıştı. Biyolojik silah çalışmaları bugün ise çok değişik örtüler altında yürütülmektedir. Ülkelerin gen haritaları ortaya çıkarılmaktadır. Nüfus azaltma projesi, 1960 ve 1980 ’lerde Henry Kissinger tarafından dile getirilmeye başlanmıştır. Bugün kendisi Rockefeller ve onların Bilderberg Cemiyeti'nin sözcülüğünü yapmaktadır.

Rockefeller Vakfı, Nüfus Konseyi, Dünya Bankası, BM Kalkınma Programı (UNDP), Ford Vakfı ve diğerleri Dünya Sağlık Örgütü (WHO) ile birlikte 20 yıl boyunca, tetanos ve diğer aşıları kullanarak üremeyi önleyici aşı üzerinde çalışmıştır (Allen, 1971). 1970'lerden sonra BM örgütleri ile birlikte insanlar üzerinde denenen aşılar ile çeşitli deneyler yapılmıştır. 1978-1981 yılları arasında ABD hükümeti tarafından homoseksüellere uygulanan Hepatit B aşısı sonrası HIV mikrobu yayılmıştır. O zamandan beri Afrika'da nerede ne kadar maden varsa o kadar HIV/AIDS ve iç savaş olmuştur. Bu hastalıklardan Batının çokuluslu madencilik, ilaç ve gıda şirketleri hep karlı çıkmıştır. İlaç şirketlerinin başında Pfizer, Merck\&Co, Novartis GlaxoSmithKline, Amgen, Astra Zeneca, Eli Lilly, Abbott sayılabilir.

2000 yılından itibaren ise hedef biyolojik savaşı kazanmaktır. Bugün ABD'de 300'den fazla bilimsel kuruluş içinde 12.000 kişi biyolojik savaşta kullanılacak patojenler üzerinde çalışmaktadır (Ross, 2006). Bu kirli oyunun içine, WHO gibi BM organları, çeşitli araştırma kurumları, biyo-savaş laboratuvarları dâhil edilmiştir. Amaç sadece para kazanmak değil, dünyanın ve insanlığın geleceğine, kimlerin yaşayacağına ve yöneteceğine karar vermektir. Zaten birçok politikacı, iş insanı, kurumlar ve medya bunların esiridir. Çoğu filantropi yolu ile sanki kendini insanlığa adamış maskesi içinde sahnededir.

\section{Yeni Jeopolitik}

Dünyayı yönetmeye hazırlanan milyarderler sınıfı tarihin sonunun geldiğine ve artık sadece genetiğiyle oynanan mikropların değil insan denen varlığın ve hayatının da yeninden şekillendirilmesi gerektiğine inanmaktadır. Binlerce yıldır biriktirdiğimiz kültür, gelenek ve pratik ne varsa tarih çöplüğüne süpürülecektir. Eğlence kültürümüz, yiyeceklerimiz ve doğa ile olan bağlarımız da buna dâhildir. İnsan hayatının sürdürülmesi geçmişte büyük ölçüde tarıma dayalı idi. Bugün sahip olunan dinler ve gelenekler eski tarım toplumlarında gelişen düşüncelerin ürünüydü. İnsanlık, Sanayi Devrimi’ne karşın büyük ölçüde tarıma ve doğaya dayalı bir yaşam sürmeye devam etmiştir.

Ziraat, yiyecek sektörü ve hayvancılık uzun zamandır dev şirketlerin baskısı altındadır. Yani feodal dünyanın son izleri de kazınmak üzeredir. Yeni dönemde laboratuvarda yetiştirilen yiyecekler, genetiği değiştirilmiş ürünler, genetik mühendisliği ile üretilen toprak mikropları, bilgi işleme vasıtaları, drone'lar ve diğer yıkıcı teknolojiler hayatımızı şekillendirecektir (Todhunter, 2020). Büyük başlangıç çiftçisi olmayan çiftlikler, işçisi olmayan fabrikalar, sürücüsüz arabalar, 
izleme ve taşıma dâhil her işlevde robot ve drone'lar, genetiği oynanmış tohumlar ve kimyasallar ile üretim demektir.

Peki, çiftçilere ve hayvancılıkla uğraşanlara ne olacaktır? Dünya Bankası, salgın sonrası için yeni yapısal reformlardan söz etmektedir. Yüz milyonlarca küçük çiftlik çalışanı borçlarını ödeyemediği için topraklarından koparılacak ve kendilerine yaşamlarını sürdürebilecek kadar bir gelir verilecektir. Bugün Anadolu'da yaşanan tam da budur. Köylerden şehirlere gelenler, burada devlet desteği az bir para ile yaşamaya çalışmaktadır. İronik olarak Gates Vakfi, bunun adına "toprak hareketliliğì" (land mobility) demektedir.

Koronavirüs salgını, ülkelere komşuların, dostların, tedarik zincirlerinin ne kadar önemli olduğunu göstermiştir. Tedarik zincirlerinin artan hassasiyeti başta ABD olmak üzere bazı ülkeleri bu yönde kendi kurallarını dayatarak, bunu bir silah olarak kullanmaya istemektedir. Eski moda sömürgecilerin yerini şimdi Bill Gates tipi monopoller, yeni emperyalistler almaktadır. Onların emperyalist stratejilerinde; çiftlikleri ve madenleri sahipsizleştirme, bilgiyi dönüştürme ve ticari mal haline getirme, entelektüel bilgiyi kontrol altına alarak ve ticari düzenlemeleri belirleyerek kendi tekellerini büyütmek vardır. Hiçbir şeyi olmayan insanlar devletten gelecek gelire bağımlı hale getirilirken, onlardan mutlu olmaları ve kurallara uyması istenecektir.

İçinde bulunduğumuz küreselleşme dalgası zaten kültürel çeşitliliği büyük ölçüde eritmiştir. Karanlık yıllarda sosyal temaslar da anlamını yitirmiştir. Doğa ile birlikteliğimiz azalmış, geleneksel olan ne varsa çağın eğlence ve internet kültürü içinde erimiştir. Bu kitlesel teknokratik dönüşüm gittikçe insanları kontrol ve takip edilecek bir eşya haline getirmektedir. Drone'lar ve yapay zekâ, insanın yerini almaktadır. Kitlesel işsizlik, gelir yönünden devlete bağımlılık, çipli takibe yarayan sağlık pasaportları, kitlesel aşılama dünyasında insanlıktan çıkmanız ama endişe etmemeniz ve mutlu olmanız beklenmektedir. Böyle bir durumda insanlar televizyon dizileri ve futbol maçları ile mutlu olmaya alıştırılmaktadır?

Sangınla birlikte $5 \mathrm{G}$ yani beşinci nesil iletişim ağlarına geçiş dönemindeyiz. Her türlü eşyaya entegre olabilen "Eşyaların İnterneti" hayata geçtiğinde bunun en çok küresel tedarik zincirlerine etkisi olacaktır. Bu yolla gönderilecek kötü amaçlı virüsler ile istenmeyen eşyalara zarar verilmesi planlanmıştır (Metzger ve Haydock, 2020). 2021'de yeni kötü amaçlı yazılımların devreye girmesi beklenmektedir. İleri teknolojiye sahip ülkeler, teknoloji bağımlısı ülkelere karşı yeni standartlar ve kurallar getirmek peşindedir. Askeri ve istihbarat amaçlı kurumlar da kullanılan bilgisayar donanımlarıyla piyasada satılmayan yeni bir sisteme dönüştürülmektedir. Böylece sızmaların önüne geçilecektir.

2010 yılında ABD Savunma Bakanlı̆̆ İleri Araştırma Projeleri Ajansı (Defense Advanced Research Projects Agency, DARPA), bu genetik teknolojisinin insanların genetik yapısını geliştirmek ve bozmak için de kullanılabileceğini açılamıştır. Şimdi koronavirüs DARPA'nın karanlık gündemine yeni bir yön vermiştir (Webb, 2020): Biyoteknolojiyi silah haline getirerek kitlesel ölümlere yol açmak.

\section{Yeni Yaşantı ve Dijital Kimlik}

Bill Gates'in kurduğu Küresel Aşı ve Bağışıklık İttifakı (Global Alliance for Vaccines and Immunization, GAVI) ve bunun etrafındaki araştırma merkezleri, Dünya Sağlık Örgütü, Gates Vakfi, Dünya Bankası, UNICEF ve ortakları olan eczacılık sektörünün devleri tarafindan desteklenmektedir. Bill Gates, herkesin bir aşı pasaportu olmasını istemektedir.

Aşılarla hidrojel nanoteknoloji derinin altına enjekte edilmektedir Endişeler, duygular, yumurtlamalar, vitaminler vb. dahil olmak üzere vücuttaki temel olarak her şeyi izlemek için cep telefonları ve yapay zeka ile arayüz oluşturmak mümkün hale gelebilmektedir. Bir kez enjekte edildiğinde, bu nanoteknoloji vücuda yayılmaktadır ve bilim insanları bunun DNA'mızı nasıl 
etkilediğini bilmemektedir. RNA ve DNA teknolojisinin bir kişinin vücudunda kalıcı ve bilinmeyen genetik değişikliklere neden olacağı savunulmaktadır (Madej ve Taliano, 2020). Amaç, eskisi yerine yeni türler yaratmak ve istenmeyenleri yok etmektir. Deneysel COVID aşıları, yeni dünya düzeninin kurallarını dikte etmek isteyenlerin bir ürünü olarak ortaya çıkmaktadır.

Böylece, ise küresel bir elektronik kimlik tanımlama programına (ID 2020) entegre olunması sağlanabilecektir (Koenig, 2020a). Yani aşıda küresel nüfus azaltma misyonu olan Gates'in imzası vardır. Bugünün insan nüfusu dünyanın taşıyacağı kapasiteye göre çok fazla ve buna doğum kontrolü ile çözüm bulunamaz durumdadır. Artık güçlü ve yetenekli olanlar seçilecektir.

Üstelik bugün insanların yaptığı işlerin üçte biri 2025 yılına kadar yazılımlar, robotlar ve akıllı makineler tarafından yapılmaya başlanacaktır. Robotlar yemek istemez, ücretli değildir ve onların sağlık sorunları yoktur. 2029 yılına kadar robotlar, zekâ ve işlev olarak insan seviyesine gelecektir. İnsanların yüzde 80'inin bu dünya düzeninde yeri olacaktır. Bunların yüzde 84 'ü dijital bir işte, yüzde 83'ü uzaktan, yüzde 50'si otomasyon işlerinde çalışacaktır (World Economic Forum, 2020). İşsizlik yüzde 30 civarında olurken, soy gelişim planına göre bir nüfus azaltması yapılacaktır. Bu işte nanoteknolojik aşılara entegre $5 \mathrm{G}$ ve $6 \mathrm{G}$ teknolojileri ile insan davranışlarını takip edilerek karar verilebilecektir. Kalanlar da zaten teknolojik esir olacaktır.

Citi Group'un yaptırdığı bir başka araştırma, teknoloji değişiminin kapsamının da arttığını gösterilmektedir. Büyük veri devrimi ve makine öğrenimi algoritmalarındaki gelişmeler, bir zamanlar insan olduğu düşünülen bir arabada gezinme veya el yazısını deşifre etme gibi görevler de dahil olmak üzere daha fazla mesleğin teknoloji ile değiştirilebileceği anlamına gelmektedir. İstihdam üzerine yapılan araştırma, ABD'deki işlerin yüzde 47'sinin bilgisayarlaşma riski altında olduğunu göstermiştir. Otomasyon risklerinin aslında diğer birçok ülkede daha yüksek olduğunu dikkat çekilen rapora göre bu oran OECD'deki verilere göre yüzde 57'ye, Hindistan'da yüzde 69'a, Çin'de ise yüzde 77'ye çıkaracaktır (Frey, Osborne ve Holmes, 2015).

Öte yandan, İngiliz biyometrik firması iProov ve siber güvenlik firması Mvine, dijital pasaport geliştirmiştir. İngiliz havayolları ve otelleri pasaportu desteklemektedir. Bu pasaport, sizin seyahate çıkmanıza veya sinemaya ve restorana gitmenize, sosyal faaliyetlere katılmanıza engel olabilir. İngiltere'den sonra Danimarka, Kanada gibi ülkelerde de pasaporta ilişkin tartışmalar başlamıştır. Bunun normale dönüş için gerekli olduğunu iddia edenler vardır. İsrail'de Netanyahu, kamuya açık yerlere girilmesi için "yeşil pasaport" verilmesinden bahsetmiştir. Bu pasaportlar izleme ve takip imkânı da sağlayacaktır. Yani Büyük Birader'in küresel gözetleme sistemi zorunlu dijital kimlik ile çok daha etkin bir hale gelecektir.

Biyometrik dijital kimlik yeni değildir. İşe önce yoksul ve uzaktan kontrol edilen Batı Afrika'dan başlanmıştır. Bill Gates'in GAVI'si, Mastercard ve yapay zekâ destekli "kimlik belgeleme" şirketi Trust Stamp bu işin arkasındadır. 2018'de "Sağlık Kartı" (Wellness Pass), dijital aşı kayd1 ve kimlik sistemi olarak üretilmiştir (Diego, 2020). Mastercard, bu kart modelini bir ödeme sistemi olarak kullanma arayışı içindedir. Haziran 2020'de GAVI, Mastercard'ın Sağlık Kartı'nın koronavirüs kapsamında kullanılacağını açıklamıştır.

Biyometrik kimlik sistemi pek çok ülkede yayılmış ve Türkiye'ye de gelmiştir. Yüzünüz, avuç içiniz ya da parmak izinizin ölçüleri kodlanarak artık sonsuza kadar izinizi kaybettiremez hale geliyorsunuz ya da hangi kimliğe girerseniz girin asıl kimliğiniz ortaya çıkıyor. Artık reklam şirketleri ya da arayanlar kimliğiniz olmasa da internetteki resminizden sizi tanıyabilir. Bunun için "yüz tanıma" (face recogniton) programları vardır. Amerikalılar bunu geçen yaz protestocuları tespit etmek için kullanmıştır. Şimdi bu COVID-19 ile mücadele adı altında yeni bir çehre kazanacaktır. Sadece sağlık değil, finansal takibiniz de sağlanacaktır. Temassız ödemeler bunun ilk adımıdır. Ama daha önemlisi nerede olursanız olun tanınacaksınız. 


\section{Karanlık Zamanlar}

İnsanlık tarihinin çok önemli bir evresindeyiz. Zaten 2035 yılından sonra başka bir dünyada çipli insan modeli (insan 2.0) ile yaşayacağımızı, Dördüncü Sanayi Devrimi ile birlikte ortalığ1 robotların saracağını biliyorduk ama COVID-19 başka bir katalizördür. Bizi bekleyen büyük dönüşüm, tek dünya devleti kurma peşindeki elitin salgın planları ile iç içe geçmektedir. Daha açıkçası koronavirüs; güçlü finansal çıkarları olan elitin ve yozlaşmış politikacıların tüm dünyayı işsizlik, iflas ve ümitsizlik ortamına sürükleyerek tek dünya hükümeti kurma amaçlarına giden yolda bir giriş hikâyesi ve sadece başlangıç; "büyük başlangıç”tır. Bu amaca giden yolda şunlar gerçekleştirilecektir: İnsanlar karantinalar altında yaşayacak, yavaş yavaş tüm özgürlüklerini ve sonunda yaşama haklarını da kaybedeceklerdir. Bütün ulusal ekonomiler yok edilecek, küçük ve orta ölçekli şirketler gittikçe daha büyükleri tarafından yutularak, sermaye elitlerinin elinde toplanacaktır. Yeni dünya düzeni kurulduğunda geliştirdikleri teknolojilerle ne yememiz ve nasıl yaşamamız gerektiğine karar vereceklerdir. Aşıya bağımlı bedenimizdeki dijital kimliğimizle küresel gözetleme ve takip programına tabi olacağız. Sadece insanlar değil doğadaki her şey takip edilecek ve insan da dâhil her şeyin ticareti yapılacaktır. İşe yaramayanlar ve fazla görülen sıradan insanlar nüfus azaltmasına tabi tutulacaktır.

Ulusal ekonomiler için gelir, iş, üretim, ticaret, altyapı ve sosyal hizmetler gibi çözümler gittikçe anlamsız hale gelmektedir. Kaynak olmadığı sürece ekonomiyi istikrara kavuşturma tedbirleri, nafile bir tur olmaktan öteye gidememektedir. İnsanlar dışarı çıkamadıklarından sosyal ilişkiler ve kurumlar ölmekte, pek çok şey unutma sürecine girmekte ve sosyal medyaya bağımlı hale gelinmektedir. İnsanların hayatları yok edilirken, sivil toplum gittikçe istikrarsızlaşmaktadır. Boş okullar, boş havaalanları, iflas etmiş alışveriş merkezleri, dükkânlar, restoranlar.

Karanlık zamanlara korku iklimi hâkimdir. Gerekli olan psikolojik baskı buradan gelmektedir. Sosyal medyanın gelişmiş olması tam da bu dönem ile örtüşmektedir. Elitin COVID-19 darbesi muhtemelen insanların psikolojik durumlarının bozulduğu, aile içinde bile şiddetin başladığı, insanların geçim imkânlarını kaybettiği ve açlıktan ölümlerin görüldüğü bir zamanda gelecektir (Burrowes, 2020a).

İçinde bulunduğumuz dönemin kararları üç adresten gelmektedir: Wall Street, Dünya Ekonomik Forumu (World Economic Forum, WEF) ve milyarderlerin vakıfları. WEF, dünyanın bin büyük şirketi ile geleceği şekillendirmek için bir platform oluşturmaktadır. Bu, sadece bir şirketlerin bir araya getirildiği bir ağdır (network). Bu ağın dışında kalanlar (yerliler, yoksullar, Asyalı ve Afrikalılar, çiftçiler, engelliler vs.) sıradan insanlar olarak görülmektedir (Shiva, 2020). Bu konular kamuoyunun önüne pek çıkarılmamaktadır ve çok az kişi bunlar hakkında bilgi sahibidir. Çünkü ortada adına küresel sermaye dediğimiz ve Türkiye gibi çevre ülkelerde de şubeleri olan geniş bir çıkar ağı vardır.

\section{Büyük Plan}

COVID-19 ile başlayan dönem büyük planın ilk adımıdır. Kırılmış ve bölünmüş, ekonomisi çökmüş ve korku içinde bir dünyaya hükmetmek istenilmektedir. Teknolojileri bir araya getirerek fiziksel, dijital ve biyolojik sınırları ortan kaldırmayı hedeflenmektedir. Robotlaşmış bu dünyada kalpler çalışmayacak, sevgi kaybolacaktır. Ne yaptığımız değil, kim olduğumuz da değişecektir. Bütün bunların ötesinde yonga takılmış, beyninden internete bağlı insandan (insan 2.0) makine takviyeli insana yani insan-makine statüsüne geçilecektir (insan 3.0).

Özetle, korona krizinin tetiklediği küresel darbe, yeni bir çağı, insan özgürlüklerini yok eden yeni bir uluslararası ekonomik düzeni temsil etmektedir (Nordangård, 2020). Yeni tekno-totaliter rejimin yol haritası "akıllı iklim," "sağlıklı dünya" gibi söylemlerle bizi tiranlar dünyasında zorla yaşamaya çağırmaktadır. WEF içindeki teknoloji devi bu tiranlar, kendi gündemlerini Dördüncü 
Sanayi Devrimi içinde hayata geçirmek için dijitalleşmeyi anahtar unsur olarak görmektedir ve altı ayrı alanda çalışmaktadır (Burrowes, 2020b): (1) Yapay zekâ. (2) Uydular. (3) Robotlar. (4) Drone'lar. (5) Eşyaların İnterneti. (6) Sentetik yiyecekler.

On yıllardır hazırlanan, çok geniş kapsamlı ve inceden inceye düşünülmüş bir plan vardır. Yeni dünya düzeninde sınırlar olmayacak ve tek bir hükümet kurulacaktır. Yapay zekâ; işimizi, yiyeceğimizi, paramızı ve özel hayatımızı kontrol edecektir. Özgürlüğümüz sonsuza kadar elden gidecektir. Y1llar geçtikçe sistem derinleşecek, geçmiş unutulacak ve dünya bir web sitesi haline gelecektir.

İnsanlar için geliştirilen bu stratejiler, ulus-devletlere de uygulanacaktır. Dünya Bankası Grubu Başkanı David Malpass, karantina uygulanan ülkelerin ayağa kalkması için yardım edeceklerini söylemektedir. Bu yardım, neoliberal reformlar karşılığ 1 verilecek; kamu hizmetleri yok edilecek ve sonra sira asıl plana gelecektir (Zumbrun ve Harrison, 2020). Finansal kurumlara olan borçların karşılığında dev tekellerin kucağına düşülecek ve Bill Gates’in dikte ettiği politikalar ulus-devletin ve egemenliğinin içini oyacaktır.

Halihazırda IMF, Dünya Bankası, Dünya Ticaret Örgütü gibi Washington Konsensüsü kurumlarının teşviki, desteği ve zorlamasıyla dünyanın birçok yerinde sağlıkta da neoliberal dönüşüm programları uygulamaya konulmuş ve özellikle yoksul kitleler piyasanın insafına terk edilmiştir. Ulus-devletin ekonomik ve sosyal alanda piyasa mekanizmasının hatalarına karşı daha etkin ve müdahaleci rol üstlenmesini savunan savaş sonrası dönemin gömülü liberalizmine karşı küresel elitin doktrini olan neoliberalizmin ulusal egemenlikleri aşındırmasının bir yöntemi olarak anti-sosyal devlet politikaları, kamusal hizmetlerin piyasa aktörlerine ve "yardımseverler"in filantropik çalışmalarına bırakılmaktadır (Konuralp, 2021; Konuralp ve Bicer, 2021).

\section{Büyük Başlangıç}

"Büyük Başlangıç" yani 2030’a kadar eski olan her şeyin sıfırlanacağı ve yeni bir düzenin kurgulandığı dönemdeyiz. Bu dönem temel özgürlüklerin sürekli olarak yasaklandığı, kitlesel izlemenin meşrulaştığı, ilaç şirketlerinin hegemonyasının öne çıktığ 1 , büyük veriyi kontrol eden ileri teknoloji şirketlerinin (Amazon, Google, Facebook vb.) sahneyi düzenlediği bir dönemi temsil etmektedir. Öte yandan, küresel tedarik zincirlerinin ve dijital ödeme sektörlerinin önem kazandığı, biyoteknoloji ile ilgili endişelerin arttığı bir karanlığın içindeyiz.

Büyük başlangıcı, sokağa çıkma yasakları ve karantinaların getirdiği dönüşüm ile aslında örtülü olarak Dördüncü Sanayi Devrimi hayata geçmektedir. Eski şirketler iflasa sürüklenirken, tekellerin kucağına düşüyor ve COVID-19 öncesi ekonominin büyük sektörleri yok edilmektedir. Şimdi ekonomilerin yeniden yapılanma ve pek çok işin yapay zekâ kullanan makinelere devredilme zamanıdır.

2030 yılına geldiğinizde hiçbir şeyiniz olmayacak ama mutlu olacaksınız. İnternetten ısmarladığınız bir eşya, bir robot tarafından paketlenmiş olarak beklediği deposundan bir drone vasıtası ile alınarak size getirilecektir. Bu işin kazananı Amazon gibi dev şirketler olacaktır. Üretimde, paketlemede veya dağıtımda insan eli değmeyecektir. İnsanlar üzerinde tam hâkimiyetin sürmesi ve böyle bir düzen kurulması için virüs ve bakterilerle dolu bir dünya hikâyesi sürecektir.

İşsiz insanlar için bir çeşit temel gelir olacak ve borçları karşılı̆̆ında devlete ya da finansal kurumlara bağımlı hale geleceklerdir. Artan finansallaşmaya koşut olan borçluluk durumu, bir çeşit yeni tahakküm metodu olarak karşımıza çıkmaktadır (Boyraz, 2018, s. xxi). WEF'in öngördügü gibi "sürdürülebilir tüketim" ve "gezegenin kurtarılabilmesi" maskesi altında insanlara ihtiyaçları olan her şey "kiralık" olarak verilecektir. Ama en tepede küçük bir elit tek dünya 
düzeninde her şeyin gerçek sahibi olacaktır. Milyarlarca insanın ihtiyaç fazlası görülen eşyalarına el konacak ya da aslında insanlar soyulacaklar. Her anımız gibi alış verişlerimiz de takip edilecek ve her şey çevrimiçi olacaktır.

İnsan, hayvan, bitki, eşya yani her varlık dijital olarak etiketlenecek ve izlenecektir. Bunlara bir ticari mal gözü ile bakılacak ve ticareti yapılacaktır. Hayatınıza siz değil, sizin bedeninizle temas kuran yapay zekâ karar verecektir. Tıpkı Ortaçağ' 'n feodal sisteminde olduğu gibi bunun kendiniz için güvenli ve iyi olduğunu düşüneceksiniz. Klasik şiddet yerine moral hapları ile rahatlayacak ya da sanal hapishaneye gideceksiniz.

Büyük Başlangıca Çin ve Rusya gibi ülkelerin katılımı ayrı bir senaryodur. Çin'den ilk adım kripto dövize dayalı finans ağına katılmak olmuştur. Çünkü Çin ekonomisi, küresel sisteme ve ABD'ye bağımlıdır. ABD'nin Merkez Bankası FED'in (Federal Reserve System) sistemi yerine altına dayalı kripto paraya geçmesi beklenmektedir. Bu Rothschild'in yüz yıllık hayali olan dünya merkez bankasına giden yolda önemli bir adımdır.

\section{Büyük Yalan}

Dezenformasyon, en çok korku kampanyası ile etkili olmaktadır. COVID-19'un yarattığı bu kasvetli ve endişeli ortam başta devlet yönetimleri olmak üzere, medya ortamında imkânı olan her aktöre kendi gündemini uygulaması için firsat sağlamaktadır. Yaşadıklarımıza bir bakalım. Önce geçenlerde bir "öldürücü virüs” hikâyesi ortaya çıkmıştır. Bu, daha sonra tüm dünyada çok ciddi bir finansal krizi tetiklemiştir. Sonrasında 193 ülkenin 190’ında karantinalar başlamış ve ulusal ekonomiler kapanmıştır. Birkaç ay sonra "ikinci dalga" ilan edilmiştir, yani "virüs bitmedi" denilmiştir.

ABD'de COVID-19 öncesi halkın yüzde 15-20'si yoksulluk sınırının altında yaşamaktaydı. Şimdi durum daha da vahimdir ve halk gittikçe militanlaşmaktadır. Avrupa'daki ayaklanmaları karantina dönemi bastırmaktadır. Yalanın gerçek olduğu bir dünyada, her şey ters yüz olmuş durumdadır. Sanki geriye dönüş yok gibi. Korku kampanyası devam etmektedir. Ne zaman normale dönülecek? Dünyadaki tüm insanlar aşı olduğunda. Çünkü para o zaman kazanılacaktır. Aşı geliştirme çalışmaları her şeyden önce kar amaçlı ve hükümetlerden çok Big Pharma'ya yani medikal derin devlete hizmet etmektedir. ABD daha aşı tam anlamıyla piyasa çıkmadan 100 milyon doz, AB ise 300 milyon doz ısmarlamış ve bu Big Pharma için büyük paradır. Bu paranın içinde insanların vergileriyle siyasal yozlaşmaya ödenecek bedeller de vardır.

Büyük Başlangıç'ın diğer önemli bir aşaması; genetiği değiştirilmiş yiyeceklerin kullanılması ile ilgili düzenlemelerin hayata geçirilmesidir. Bunlar WEF tarafından bilimsel çalışmaların sonuçları şeklinde gerekçelendirilmeye çalışılacaktır ama bu sahte bir bilimdir. Artık üretimde makineler olacak, insan sistemden çıkacaktır. Yediğimiz her ürünün her bir lokması dijital verilerle üretilecektir. Yani tarımda ürettiğimiz organik yiyeceklerin yerini genetiği değiștirilmiş yiyecek laboratuvarları alacaktır. Bunun adı "sağlıklı ve sürdürülebilir beslenme" olacaktır. Coğrafi ve bölgesel biyo-çeşitlilik ortadan kalkacaktır.

$\mathrm{Bu}$ aslında küresel bir darbedir. Karantinalar ve ekonomilerin kapanması bir kitle imha silahı vazifesi görmektedir. Tıpkı içinde bulunduğumuz salgın döneminde olduğu gibi ekonomiler büyük krizde olduğu halde çatlak sesler susturulacak ve aşılara karşı çıkanlar psikopat muamelesi görecektir. İnsanların özgür ve doğal hayatları yok edilecek, sivil toplum huzursuz hale gelecektir. Medya sansürü nedeni ile arka planı göremeyeceğiz. Bu sürecin pazarlanma motoru Google, insanların doğru bilgiye ulaşmasını önlemek için maske takmaktadır. Twitter, aşı aleyhine olan mesajlar1 engellemektedir.

Karantina hikâyeleri medya dezenformasyonu, online sansürler, sosyal mühendislik ve korku kampanyası ile birlikte yayılmaktadır. Bunları ortaya koyacak çalışmalar yasaklanmaktadır, 
marjinalize edilmektedir. İnsanları karantinada tutmak için kullanılan en büyük yalan; rakamlar, yeni dalgalar ve aşı umutları. Tıp doktorları tehdit edilecek, üniversitelerden resmi öğretinin d1şına çıkılmaması istenecektir. Birçok ülkede pek çok doktor ya da sağlık çalışanı farklı düşündüğü için tutuklanmıştır.

Salgın döneminin yasaklamalara uygun ortamı ve artan sosyal medya kontrolü devlet yönetimlerini gittikçe daha otoriter hale getirecektir. Bu rejim sonuçta tüm protesto ve direnişleri ezerken, insanları yaşadıkları hayatı kabul etmek zorunda bırakacaktır. Ancak, bu devlet tek dünya devleti için bir geçiş formu olacaktır. Sonuçta devletler de yaşamayacak hale gelecek çünkü küresel elitin düzenlemelerine yenik düşecektir. COVID aşı programı ve dijital pasaportunuz, küresel totaliter rejime sizi bağlayacaktır. Bunun adına da "küresel yönetişim" diyeceklerdir.

\section{Küresel Elitin Yol Haritası}

En tepede CFR, Chatham House ve Bilderberg gibi bildiğimiz kurumları olan küresel sermaye son yıllarda yeni bir örgütlenmeye gitmiştir. Dünya Ekonomik Forumu, yeni dünya düzeni ve dünya hükümetinin planlama ve uygulama süreçlerinde şu anda etkin görevdedir. Birleşmiş Milletler ve onun Dünya Sağlık Örgütü gibi alt kuruluşları da onları meşrulaştırma ve uygulama rolündedir. Bunlara Avrupa Birliği, Dünya Bankası, IMF ve Uluslararası Suç Mahkemesi'ni ekleyin. Bütün kanunsuz kurallar ve düzenlemeler bu ekibin kontrolü altındadır.

Virüsler ve aşılar ile ilgili planlar 1990'larda sözde yazılımcı olan Bill Gates'e bu görevin küresel elit tarafından verilmesi ile başlamıştır. Sadece aşılar ile sınırlı kalmamış, genetiği değiştirilmiş tohumlar üzerinde de büyük bir proje yürütmektedir. Yani gelecekte ne yiyeceğimize de onlar karar verecektir. Aşı projeleri başta Afrika ve Hindistan olmak üzere pek çok insanı öldürdü ya da kısır bırakmıştır. Salgın hastalık işleri ise Big Pharma adı verilen on dev ilaç şirketinin 1990'lardan beri ürettiği Sars, Mers, H1N1 gibi pek çok suni salgının sözde aşısının bulunması kapsamında yürümektedir.

Rockefeller'ın 2010 yılında yayımlanan "Karantina Senaryosu” (Koenig, 2020c), COVID19 çıkmadan önce, 2019'da New York'ta Event 201 salgın hastalık tatbikat1, Bill Gates'in arkasında olduğu Wuhan'daki biyoloji laboratuvarının elemanlarının Kanada'daki başka bir laboratuvardan yetiştirilmesi önemli aşamalardı. COVID-19 ile gelinen aşama yani Ocak 2020 tarihi "büyük başlangıç" olarak adlandırılmaktadır. Uzun bir zamandır yapılan hazırlıkların en ciddi uygulaması ve inceden inceye bir plan vardır ortada.

2030 yılına kadar büyük başlangıç içinde ülkelerin ekonomisi çökertilerek ya da diz çökertilerek yeni bir aşamaya, yeniden yapılandırılmış küresel ekonomiye geçilecektir. Dünya Bankası, IMF ve finansal kuruluşlar borç sarmalındaki ülkeleri kontrollerinde tutmaktadır. Neoliberal sistem içinde kurallarına uymayanlar cezalandırılacak ve borç ekonomisi sonunda her şeylerini uluslararası tekele satacaktır.

Karantinalar devam ederken, ekonomiler çökerken şu sıralar en önemli gündemleri zorunlu aşıyı ve dijital kimliği dayatmak yani ID2020 projesinin hayata geçmesidir (Koenig, 2020b). Böylece nüfus kontrolü ve aşı bağımlılığında önemli bir safha tamamlanacaktır. Bu küresel gözetleme ve takipte önemli bir aşama, sonuçları sadece sağlıkla ilgili değil, tüm sosyal hayatınız ve harcamalarınız da takip altında olacaktır. Aşı işinin başında Bill Gates'in başında olduğu GAVI ve Big Pharma vardır. Paralar Bill ve Melinda Gates Vakfı ve Dünya Sağlık Örgütü bütçesinden gelmektedir.

WEF, ID2020'yi uygulamada ana rol almıştır. Gerekçeyi şöyle açıklamıştır: SDG (UN Sustainable Development Goals) 16 kapsamında "2030 yılına kadar, sürdürülebilir kalkınma ve ada- 
let sağlamak için her seviyede hesap verebilir ve kapsayıcı kurumlar inşa ederek barışçı ve kapsayıc1 toplumları geliştirmek (Birleşmiş Milletler, 2020)." Dünya Ekonomik Forumu, dolara dayalı bir yaptırım stratejisi içinde ülkelerin varlıklarına el koymayı hedeflemektedir. 2021 yılı yaz aylarında yapılacak WEF zirvesinde uygulama planı ele alınacaktır (Chossudovsky, 2020). Diğer taraftan, küresel elitin doktrini olan açgözlü neoliberalizmin büyüme ve daha fazla kar elde etme güdüsünden başka bir motivasyonu olmadığg halde sözde sürdürülebilirlik hedeflerini bir arada götürmek ve çevreci duyarlılıkları gerçekten özümsemek olanaksızdır (Konuralp, 2020).

Büyük Plan, BM'nin Gündem 2030 planı ile de uyumludur. BM'nin Gündem 2030'u ve SDG'yi uygulamak için ID2020 zorunlu ve ilk uygulama Bangladeş’te okul çocuklarına zorunlu aşı ve nano-çipli dijital kimlik verilerek başlatılmıştır. Bu kimlik $5 \mathrm{G}$ ile entegre olarak tüm nüfusun kontrolünde kullanılacaktır.

Joe Biden, küresel sermayenin adamı olarak ABD'nin başına geçmektedir. Irak'ın işgal edilmesinde ABD toplumunu kandıranların başında Biden gelmekteydi. Biden, soysal bölücü, ırkçı ve şeytani Büyük Başlangıç için seçilmiş adamdır. Dünya Ekonomik Forumu'nun Büyük Başlangıç kurallarını önce ülkesinde hayata geçirecek, sonra uluslararası alanda dayatacaktır. Çünkü Biden, gerçek bir başkan olma özelliğine sahip değildir. Lobilerin ve derin devletin adamı olarak, tarihi bir misyona kukla olmak üzere başkan seçilmiştir.

\section{Sonuç}

Gerçekten karanlık zamanlarda yaşamaktayız. Henüz asıl kötü haberler daha alınmamıştır. Muhtemelen üç nesil sonra bugünlerimiz tarih öncesi, son özgür insan nesli olarak anılacaktır. Bilim, bilgi ve anlamak için insanlara liderlik eder ama bu sefer büyük bir yalana hizmet etmesi için büyük para tarafından esir alınmış durumdadır. Bu yıllardır hazırlanan büyük bir komplonun parçasıdır. Zenginlerin tek dünya hükümeti için insanlığı yok edecek büyük bir planın başlangıç aşamasındayız. Ellerinde olan medya ile yaratılan korku dünyasında evlerimize hapsedildik ve bizi götürecekleri sahte geleceğe inanmak ve razı olmak için beklemekteyiz.

Şimdi herkesin içinde bulunduğu korku ve uyuşukluğu atıp kendisi ve gelecek nesilleri için bir şeyler yapma zamanıdır. Ya kolektif histeriyi, kıtlığı, yoksulluğu, işsizliği yeneceğiz ya da tarihe son özgür nesil olarak geçeceğiz. Yapmamız gerekenler şu şekilde sıralanabilir:

(1) Korku kampanyası ve medya dezenformasyonunu, Big Pharma'nın aşı programını ve dijital kimliği boşa çıkarmak,

(2) Küresel elitin ülkelerin sosyal yapısı ve ekonomisine zarar vermesini önleyecek bir uluslararası dayanışma hareketi oluşturmak.

“Karşı koyabiliyorsam özgürüm, o yüzden ben, benim!’ Karşı koyamadığımız günler geldiğinde zaten özgür değiliz demektir.

\section{Kaynakça}

Allen, G. (1971). None Dare Call It Conspiracy. G S G \& Associates Pub.

Barkan, J. (2013, Eylül). Plutocrats at Work: How Big Philanthropy Undermines Democracy. Dissent Magazine. https://www.dissentmagazine.org/article/plutocrats-at-work-how-big-philanthropy-undermines-democracy adresinden erişildi.

Birleşmiş Milletler. (2020). Goal 16: Promote just, peaceful and inclusive societies. Sustainable Development Goals. 12 Ocak 2021 tarihinde https://sdgs.un.org/goals/goal16 adresinden erişildi.

Boyraz, C. (2018). Türkçe Baskıya Sunuş: Krizden Sonra? Küresel Kriz Sonrası Siyasi-İktisada Genel Bir Bakış. R. Albritton, B. Jessop ve R. Westra (Ed.), Siyasi Iktisat ve Küresel Kapitalizm: 21. Yüzyıl, Bugün ve Yarın içinde (ss. xiii-Xxv). İstanbul: Bilgi Üniversitesi Yayınları.

Burrowes, R. J. (2020a). The Elite's COVID-19 Coup against a Terrified Humanity: Resisting Powerfully. Transcend Media Service. 12 Ocak 2021 tarihinde https://www.transcend.org/tms/2020/04/the-elites-covid-19-coupagainst-a-terrified-humanity-resisting-powerfully/ adresinden erişildi. 
Burrowes, R. J. (2020b). Corrupt Science and Elite Power: Covid-19 “Techno-Slavery" and the "Great Reset" Are Now Imminent. Global Research. 12 Ocak 2021 tarihinde https://www.globalresearch.ca/corrupt-science-elite-powertechno-slavery-imminent/5731026 adresinden erişildi.

CDC. (2020). CDC's Diagnostic Test for COVID-19 Only and Supplies. CDC. 12 Ocak 2021 tarihinde https://www.cdc.gov/coronavirus/2019-ncov/lab/virus-requests.html adresinden erişildi.

Chossudovsky, M. (2020). The 2020-21 Worldwide Corona Crisis: Destroying Civil Society, Engineered Economic Depression, Global Coup d'État and the "Great Reset". Global Research. 12 Ocak 2021 tarihinde https://www.globalresearch.ca/the-2020-worldwide-corona-crisis-destroying-civil-society-engineeredeconomic-depression-global-coup-detat-and-the-great-reset/5730652 adresinden erişildi.

Coleman, J. (2006). The Conspirators' Hierarchy: The Committee of 300. World in Review.

DeGraw, D., Engelbrecht, T. ve Demeter, K. (2021). COVID Tests Scientifically Fraudulent, Epidemic of "False Positives". Global Research. 12 Ocak 2021 tarihinde https://www.globalresearch.ca/national-security-alertcovid-tests-scientifically-fraudulent-epidemic-false-positives/5720271 adresinden erişildi.

Diego, R. (2020). Africa to Become Testing Ground for “Trust Stamp" Vaccine Record and Payment System. Mint Press News. 12 Ocak 2021 tarihinde https://www.mintpressnews.com/africa-trust-stamp-covid-19-vaccine-recordpayment-system/269346/ adresinden erişildi.

Engdahl, W. F. (2007). Seeds of Destruction: The Hidden Agenda of Genetic Manipulation . Montreal: Global Research. https://www.pandora.com.tr/kitap/seeds-of-destruction-the-hidden-agenda-of-genetic-manipulation/612672 adresinden erişildi.

Fleury, B. (2015). The Negro Project: Margaret Sanger's Diabolical, Duplicitous, Dangerous, Disastrous and Deadly Plan for Black America. Dorrance Publishing Co.

Freeman, M. (2020). SARS-CoV-2: The Stitched Together, Frankenstein Virus. The Freedom Articles. 12 Ocak 2021 tarihinde https://thefreedomarticles.com/sars-cov-2-stitched-together-frankenstein-virus/ adresinden erişildi.

Freeman, M. (2021). 10 Things You Need to Know about the Experimental COVID Vaccines. The Freedom Articles. https://thefreedomarticles.com/10-things-to-know-experimental-covid-vaccines/ adresinden erişildi.

Frey, C. B., Osborne, M. A. ve Holmes, C. (2015). Technology at Work v2.0: The Future Is Not What It Used to Be. Oxford Martin School. https://www.oxfordmartin.ox.ac.uk/publications/technology-at-work-v2-0-the-future-isnot-what-it-used-to-be/ adresinden erişildi.

Hunt, T. (2008, 17 Nisan). The business of giving. The Guardian. https://www.theguardian.com/commentisfree/2008/apr/17/3 adresinden erişildi.

Hürriyet. (2013). Traktörden 10 milyar dolar kazand. Hürriyet. 12 Ocak 2021 tarihinde https://www.hurriyet.com.tr/ekonomi/traktorden-10-milyar-dolar-kazandi-24733546 adresinden erişildi.

Koenig, P. (2020a). Coronavirus - No Vaccine Is Needed to Cure It -. Fort Russ. 12 Ocak 2021 tarihinde https://fortruss.com/amp/2020/04/coronavirus-no-vaccine-is-needed-to-cure-it/ adresinden erişildi.

Koenig, P. (2020b). The Coronavirus COVID-19 Pandemic: The Real Danger is “Agenda ID-2020" \& The COVID-19 Pandemic from a Global Environmental Health. Journal of Environmental \& Analytical Toxicology, 10(7). doi:10.37421/2161-0525.10.615

Koenig, P. (2020c, 27 Nisan). COVID-19, We Are Now Living the "Lock Step Scenario". Global Research. 12 Ocak 2021 tarihinde https://www.globalresearch.ca/rid-ourselves-war-virus/5710882 adresinden erişildi.

Konuralp, E. (2020). Between neoliberal appetence and environmentalist reservations: the political economy of sustainable aviation. International Journal of Sustainable Aviation, In press.

Konuralp, E. (2021). In What Ways Does the Embedded Liberalism Literature Differ from the Liberal-Individualistic IPE? A. Haşimov ve M. Şabanov (Ed.), Al Farabi Journal 9th International Conference on Social Sciences Full Text Book içinde (ss. 124-131). Nakhchivan: Farabi Publishing House.

Konuralp, E. ve Bicer, S. (2021). Putting the Neoliberal Transformation of Turkish Healthcare System and Its Problems into a Historical Perspective. Review of Radical Political Economics, 53(4). doi:10.1177/04866134211005083

Lendman, S. (2021). Britain to Issue Vaccine Passports. Stephen Lendman. 12 Ocak 2021 tarihinde https://stephenlendman.org/2021/01/britain-to-issue-vaccine-passports/ adresinden erişildi.

Madej, C. ve Taliano, M. (2020). "COVID Vaccines" and "Genetically Modified Humans". Global Research. 26 Ocak 2021 tarihinde https://www.globalresearch.ca/covid-vaccines-and-genetically-modified-humans/5718907 adresinden erișildi.

Metzger, R. ve Haydock, W. (2020). Supply Chain Intelligence for a Dangerous New World. The National Interest. 12 Ocak 2021 tarihinde https://nationalinterest.org/blog/skeptics/supply-chain-intelligence-dangerous-new-world174458 adresinden erişildi. 
Myers, P. (2001). George Soros as Rothschild Agent. Bibliotecapleyades.net. 12 Ocak 2021 tarihinde https://www.bibliotecapleyades.net/Sociopolitica/esp_sociopol_rothschild06.htm adresinden erişildi.

Nordangård, J. (2020). “The Great Reset” - Globalists' reboot of the world and their plans for us. Sott.net. 12 Ocak 2021 tarihinde https://www.sott.net/article/441490-The-Great-Reset-Globalists-reboot-of-the-world-and-their-plansfor-us adresinden erişildi.

Rose, J. (2020). Covid's Covert Reengineering of Humanity. IT. 12 Ocak 2021 tarihinde http://internationaltimes.it/covids-covert-reengineering-of-humanity/ adresinden erişildi.

Ross, S. (2006). Developing Illegal Offensive Use Bioterror Weapons. Scoop News. 12 Ocak 2021 tarihinde https://www.scoop.co.nz/stories/HL0612/S00294/developing-illegal-offensive-use-bioterror-weapons.htm adresinden erişildi.

Shiva, V. (2020). World Economic Forum's 'Great Reset' Plan for Big Food Benefits Industry, Not People. Navdanya International. 12 Ocak 2021 tarihinde https://navdanyainternational.org/world-economic-forums-great-resetplan-for-big-food-benefits-industry-not-people/ adresinden erişildi.

Stadler, B. M. (2020). Coronavirus: Why everyone was wrong -Back to Reason. Djt Solutions. 12 Ocak 2021 tarihinde https://www.djtsolutions.com/2020/07/10/coronavirus-why-everyone-was-wrong-back-to-reason/ adresinden erişildi.

Todhunter, C. (2020). Dystopian “Great Reset”: "Own Nothing and Be Happy”, Being Human in 2030. Global Research. 26 Ocak 2021 tarihinde https://www.globalresearch.ca/own-nothing-happy-being-human-2030/5728960 adresinden erişildi.

Webb, W. (2020). Coronavirus Gives a Dangerous Boost to DARPA's Darkest Agenda. The Last American Vagabond. 12 Ocak 2021 tarihinde https://www.thelastamericanvagabond.com/coronavirus-gives-dangerous-boost-darpasdarkest-agenda/ adresinden erişildi.

World Economic Forum. (2020). Resetting the Future of Work Agenda: Disruption and Renewal in a Post-COVID World. White Papers. 12 Ocak 2021 tarihinde https://www.weforum.org/whitepapers/resetting-the-future-ofwork-agenda-disruption-and-renewal-in-a-post-covid-world adresinden erişildi.

Zumbrun, J. ve Harrison, D. (2020, 9 Nisan). IMF, World Bank Face Deluge of Aid Requests From Developing World. The Wall Street Journal. https://www.wsj.com/articles/imf-world-bank-face-deluge-of-aid-requests-fromdeveloping-world-11586424609 adresinden erişildi. 